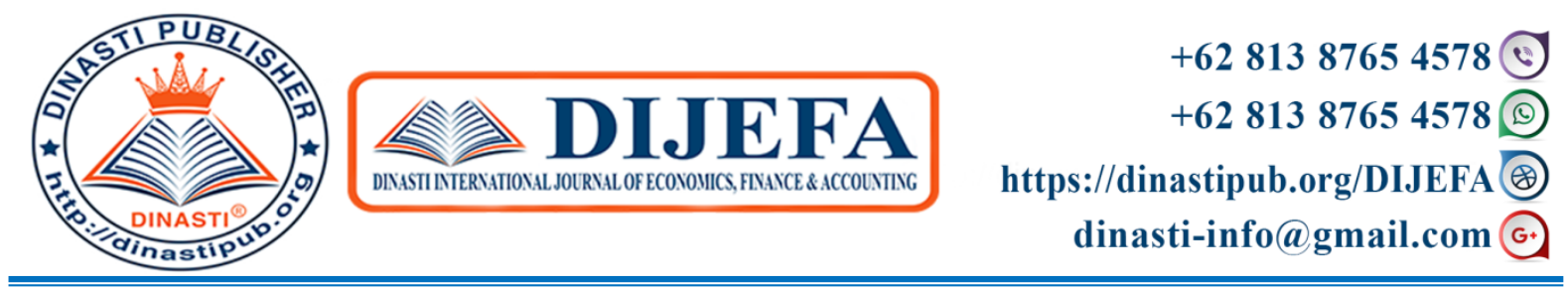

\title{
GOOD CORPORATE GOVERNANCE IMPLEMENTATION AS A PERFORMANCE AND COMPANY VALUE
}

\section{Wahyu Samari}

Mercu Buana University, Jakarta, Indonesia

ARTICLE INFORMATION

Received: $21^{\text {st }}$ May 2020

Revised: $20^{\text {th }}$ June 2020

Issued: $14^{\text {th }}$ August 2020

Corresponding author:

Wahyu Samari

E-mail:

wahyusamari20@gmail.com

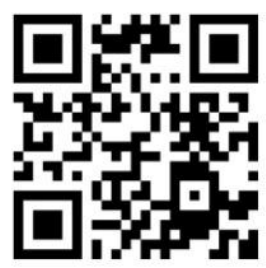

DOI: 10.38035/DIJEFA
Abstract: Good corporate governance or commonly called as GCG can be said as a tool for control of corporate decision making that is fair and accountable. So that the decision taken by the company management has considered all interested parties such as shareholders, board of commissioners, board of directors in their efforts to improve the performance and value of the company while also considering other stakeholders. Understanding GCG does not have the same definition but has almost the same spirit and values. The emphasis of GCG is on the necessity of a commitment to apply the rules of the game and to conduct business in a healthy and ethical manner. At present, where information disclosure and advancement of knowledge in all fields are advancing rapidly, encouraging capital owners and company managers to innovate and be creative in conducting their business. This condition 'forces' the company to compete as a winner in getting the maximum profit and sometimes causes problems both within the company and outside the company. A good GCG implementation will suppress problems that might arise such as bribery, corruption, investment fraud, embezzlement of funds, abuse of authority, environmental pollution, etc.

Keywords: Good Corporate Governance, Company Performances, Company Valu.

\section{INTRODUCTION}

According to Wardhani (2006), GCG is an effort to manage the company well that explains the interrelationships of the parties participating in determining the direction and performance of the company. GCG is a series of systematic activities that are used by companies to increase business success and create clarity of accountability to the company in order to maximize returns for shareholders in the long run while still considering other stakeholders based on legislation and ethical values. It can be said that the implementation of 
Business Ethics is an application of GCG principles. In accordance with SOE Ministerial Regulation Number: PER-01 / MBU / 2011 concerning the Implementation of Good Corporate Governance in State-Owned Enterprises (SOEs), GCG is the principles that underlie a process and mechanism of corporate management based on regulations legislation and business ethics.

With the existence of a good corporate management mechanism among the stakeholders in a company, this will create trust and confidence for all stakeholders. That is the important meaning of GCG implementation. Some of the benefits gained by implementing GCG are as follows:

1. Quality of decision making will be better because it involves participants in the company

2. Organizational processes are running well because they have been considered thoroughly

3. Engagement to improve services to stakeholders increases

4. Increase investor confidence

5. With investor confidence, companies can more easily get business financing

Some of the principles of GCG extracted from several can be explained as follows:

1. Responsibility

Compliance with company management with sound corporate rules and principles. Examples of the principle of responsibility are safety at work, health at work, employee insurance, tax payments, etc.

2. Independent

Professional company management without the interests and interference of any party that is not in accordance with the law and the principles of sound company management

3. Fairness

There is a fair and balanced principle in fulfilling the rights of stakeholders that must be fulfilled according to agreements and regulations of the law

4. Accountability

Clarity of company accountability so that its management is carried out effectively. The principle of accountability is to provide certainty of rights and obligations between shareholders, the board of directors, and the board of commissioners.

5. Transparent

Information disclosure must include data accuracy and timeliness of presentation to stakeholders

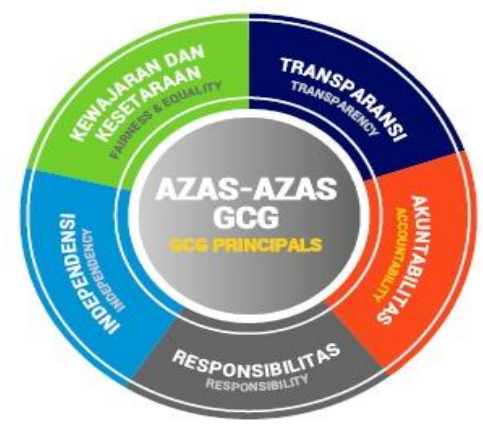

Picture.1 Principle of GCG 
The principle is a statement that is fundamental or general or individual truth that is used as a guide in thinking and doing the actions of an individual, group or company. So the principle is the "spirit" of the development and change and accumulation of the meaning of something.

So the purpose of setting these principles is to become the basis for the development and implementation of GCG in the company environment in general. The basic principles and assumptions will be a reference in the description of actions and steps taken to realize GCG and will be a guideline in testing the success of GCG implementation in a company or organization. The values contained in these principles will certainly vary according to individual and organizational beliefs and the environment in which a person / organization conducts activities. But basically not much different priorities from those mentioned above.

Many companies experience setbacks and even go bankrupt just because of the inconsistent implementation of GCG. The period 1997-2000 found several national and global companies experienced a crisis. Research experts at that time were almost the same, pointing to the issue that these companies did not implement good corporate governance (Leng, 2004; Daily et al., 2003; Faccio et al., 2001; Scott, 1999). With this setback, the impact is reducing the performance and value of the company.

\section{Formulation Of The Problem}

From the explanation of the importance, benefits and impacts of the application of this GCG in the company or organization, the writer tries to formulate the problem, namely 'Can the application of GCG have a positive impact on Company Performance and Company Value?". How do you implement GCG to have a positive impact on the company?

The implementation of GCG should facilitate and speed up the company in making decisions to advance the company, rather than on the contrary it makes the company's strategic decision making slow.

In addition, good GCG implementation will increase company performance and the value of the company. So the application of GCG must be positively correlated with company performance and value.

\section{Writing Objectives}

The purpose of this paper is to find a correlation between GCG implementation with Company Performance and Value. With the implementation of GCG, the company has actually applied the principle of fairness and transparency to all stakeholders of a company. With the existence of several parties who see each other, correct and correct the direction and policies of the company, it is expected that the company management will make the right decision for the company. Therefore the application of GCG must positively correlate to the company's performance and value.

\section{Benefits Of Writing}

The author tries to compile and identify the relationship between the implementation of GCG with the company's performance and values. So that this article can be used by organizations or companies for the development or reconstruction of the implementation of this GCG in their companies. 
In terms of theoretical knowledge, the paper will explain various theoretical points of view related to GCG and company performance.

\section{LITERATURE REVIEW}

\section{Good Corporate Governance}

In his book 'Corporate Governance and International Business (2011)', Corporate Governance according to David Crowther and Shahla Seifi explained that corporate governance can be considered as an environment of trust, ethics, moral values and selfconfidence - synergistically, carried out by all the constituent components namely stakeholders, including government, the general public, professionals, service providers, and the corporate sector. The Independent Commissioner on the Board of Commissioners is responsible for ensuring that the company has carried out social responsibility and considers the interests of all company stakeholders as well as when overseeing the effectiveness of the implementation of good corporate governance (Nasution and Setiawan, 2007).

According to the statement above, in order to implement good corporate governance, companies need to form an independent board of commissioners and an audit committee. The board of commissioners is the core of corporate governance whose function is to guarantee the implementation of the company's strategy, oversee management in managing the company and realize accountability to the company. The audit committee was formed as a remedial step to the way the company was managed, especially how to supervise the company's management. This is because the audit committee will also be a liaison between the company's management with the board of commissioners and other external parties (Palestin, 2006).

In the context of the Indonesian state, GCG is very relevant to be implemented. Indonesia has many state-owned companies that have a strategic role in determining the direction and back and forth of the Indonesian economy. With this large scale state-owned enterprise, it has a profound effect on the performance of the national economy, the creation of added value, employment, and the flow of capital flows across national borders. Without good company management, SOE companies can only become a burden on the government rather than as a driver of the country's economy.

Poor company management results in opening opportunities for certain parties who want to take the opportunity and profit from the company. Poor management will result in unhealthy practices that can harm the company. According to La Porta et al. (2000) such unhealthy practices can be:

a. Earnings manipulation

b. Sales of output or company assets below market prices

c. Placement of people who are not competent in managerial positions

d. Excessive executive compensation.

This unhealthy practice can erode the company's foundation, especially in the financial sector. With the fragility of financial fundamentals, a crisis will occur in the company and the company becomes worse. Sukrisno (2004) explains that bad company management will have implications for the company's poor performance due to the many unhealthy practices that occur within the company. 
Most companies in Indonesia adhere to the principle of the two tier board system (TTBS). This system regulates the relationship and governance between the company's management function and the company's supervisory function. In essence, TTBS is a good start-up capital for implementing GCG in the company. Daniri (2005) explains the separation of functions, duties, and authority between company managers and company supervisors will strengthen the implementation of corporate governance in a better and stronger direction. Seeing this, there are several theories that can be the basis for the application of this GCG rule, namely:

1. Agency Theory

2. Stewardship Theory

3. Stakeholder Theory

\section{Agency Theory}

The formulation of corporate governance departs from the agency theory (Agency Theory) developed by Jensen and Meckling in 1976. The theory departs from conflicts that occur between the principal and agent. Principals are parties who give mandates to agents to act on behalf of principals, while agents are parties who are mandated by principals to manage and run the company.

The agent has an obligation to account for what has been mandated by the principal to him. 'Agents' in this case is the management of the company that is considered to be acting in its own interests, not as a wise and fair party to the Principal (shareholders). The separation of ownership and differences in interests between principals and agents creates agency problems (conflicts of interest).

The surrender of the management of the company to the agent is actually based on the belief of the principal that these agents are people who are very competent and expert in running the company than the principal himself. So it is hoped that the company's management will bring maximum profit to the principal at the most cost efficient way

The agent is obliged to carry out the management of the company as well as possible to provide as much wealth as possible to the principal. In carrying out their duties, the agent has considerable authority in running this company. Problems begin to arise when agents do not carry out company management according to the above objectives. But agents think more about how to make themselves more prosperous.

As the party that runs the company, the agent has accurate information about the company's capacity, work environment, business opportunities and the company as a whole. On the other hand the principal does not have enough information about the performance of the agent. This results in 'misalignment' of information between the principal and the agent called asymmetric information. This can lead to two problems according to Jensen and Meckling (1976), namely:

1. Moral Hazard. That is the problem that occurs when the agent does not carry out what has been agreed in the collective labor contract 
2. Adverse selection. That is, a condition in which the company's shareholders cannot know whether the decision taken by the agent has been based on the information he has obtained correctly or negligence in his assignment.

\section{Stewardship Theory}

Stewardship Theory takes the foundation that agents are managers of companies with behavior that is consistent with their principal goals. This theory assumes the existence of good tolerance in an agent. Agents are seen as loyal to the company and always strive to achieve high company performance. The dominant motive that directs agents to complete their work is their desire to complete the task as well as possible. In particular, agents are understood as those who are motivated by the need to achieve intrinsic satisfaction through success in doing challenging work, carrying out responsibilities and authority as well as possible. Thus, the agent gets recognition from the leadership and other parties for its success. In this theory there is an element of motivation that is non-financial for the agent. This theory also believes that a company needs a structure that allows for effective harmonization and relations between agents and principals. In other words, Stewardship theory sees the agent as a party that can be trusted to act as well as possible in the interests of stakeholders.

\section{Stakeholders Theory}

Stakeholders Theory to position the Principal is only one of a number of important stakeholder groups. Just like customers, supplier partners, employees and the public. Gibson 2000: 247 outlines in his research that in the same way businesses have different 'functions' to meet the objectives of various stakeholder groups. In cases where there is a conflict of interest between the principal and other stakeholders, the interests of the principals must be moderated or 'sacrificed' to fulfill the basic obligations of other stakeholders.

In company law, the principal is given priority or priority status as the owner of the company. They are given the authority to elect all or most members of the Board of Directors, have the right to hire and fire senior executives and approve or reject important policies and determine corporate strategy. Because of the enormous authority and control possessed by principals based on company law, stakeholder theory tends to devote less attention to defending principals' rights. The assumption is that the principals already have the power to ensure that their interests are taken into account by the company and its agents. Stakeholders theory usually tries to show why these principal rights must be limited by the rights or interests of other stakeholder groups because the principal rights are only one of the stakeholder rights that exist in the company and already have some great authority.

From the three descriptions of theories or concepts that underlie Good Corporate Governance, a similarity lies in observing patterns of relationships or interactions between agents and principals in fulfilling the interests of each party. The effectiveness of these interactions creates a synergy or disintegration of relationships that influences the rate of growth of company value positively or negatively by considering the interests of other stakeholders. 


\section{Company Performance}

One of the company's performance parameters is Return on Assets (ROA). This ROA parameter is included in the category of profitability ratio of a company's financial statement. According to Prasinta (2012), ROA provides an overview of the rate of return that investors can obtain from their investments. With ROA, investors can also see the use of assets to be maximized and become a profit for the company, which is actually one of the goals of GCG, namely how assets are used as efficiently as possible (OECD, 2004).

The formula for calculating ROA is: Net Income / Total Assets. From this formula, it can be seen that if ROA is higher, it means that the company has effectively and efficiently managed its assets to become net income.

ROA is the ratio between net income after tax (net income) to Total Assets (Ang, 1997: 65). Return on Assets (ROA) shows a good ability of the company in utilizing funds, in the form of assets, for the benefit of the company. The higher the value of ROA, the more effective the company is in utilizing the company's assets to make profits and make profits. Dividends are part of the net income (net income) obtained by the company that is distributed to shareholders. High and low profit growth is highly dependent on the high and low Return On Assets. Profits / profits that can be distributed to shareholders are profits after the company fulfills all operational obligations, while dividends will be distributed if the company earns profits (net income). Because dividends are taken from the net profits of the company, then those profits will affect the amount of the Dividend Payout Ratio.

\section{Company Value}

There are several studies that have been carried out to examine the mechanism of GCG and its influence on firm value, and the results of these studies get combined results. Klapper and Love (2002) and Silveira and Barros (2006) formulate that the value of a company is directly influenced by Corporate Governance. The results of the study of Black et al. (2003) found that the value of public companies in Korea was influenced by the implementation of good corporate governance by the company. The same result was obtained by Rustiarini (2010) which stated that the value of the company was influenced by the mechanism of corporate governance.

Corporate governance is a system consisting of a series of procedures and mechanisms designed for corporate management based on the principle of accountability that can increase company value (share price) in the long run (Velnampy, 2013). This corporate governance system refers to a set of regulations and the existence of a mechanism used by management to direct and supervise the course of company activities. Therefore, a good and continuous implementation of GCG can enlarge opportunities to increase profits and longterm best corporate value for shareholders.

High achievement for company value can be achieved if shareholders and stakeholders can work together well and solidly in formulating the right decisions to maximize capital / equity and implement a correct and consistent corporate governance mechanism. But in reality, synchronization and harmonization of the interests of the two parties are often not in line or what is commonly referred to as the agency problem. Agency 
problems arise because of the separation of duties and responsibilities as well as conflicts of interest between company owners (shareholders) and management (company managers).

Company value is the view and assessment of investors towards the level of prosperity of a company that is often associated with stock prices. High stock prices make the value of the company also high, and increase market confidence (investors) in the company's current performance and also in the company's prospects in the future. Company value can be measured using stock prices and using ratios called valuation ratios. According to Sudana (2011: 23), Valuation Ratios are ratios associated with evaluating the performance of the shares of companies whose shares have been traded on the capital market (go public). This valuation ratio provides information on how much the community appreciates the company, so that in the end the public is interested in buying shares at a price higher than the book value. Several methods are used to measure the value of a company through an appraisal ratio, namely:

1. Price Earning Ratio (PER)

According to Brigham and Houston (2006: 110) the value of PER shows how much money is willingly spent by investors to pay every dollar of profit reported. PER can also draw a company to create profitability in the future. The greater the PER, the greater the chance for the growth of company value. PER is formulated as follows:

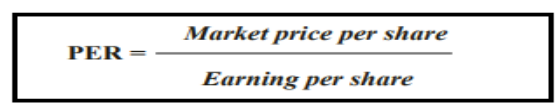

\section{Price to Book Value (PBV)}

According to Fakhruddin and Hadianto (2001) PBV is a ratio that indicates whether a stock is sold overvalued (above) or undervalued (below) the book value of the stock. PBV gives investors an idea of how high the value of the company is compared to the funds that have been invested in the company. The higher the PBV value, the higher the investor's trust will develop the company's value in the future. PBV is formulated as follows:

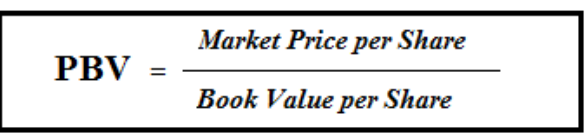

\section{Tobin's Q}

This ratio is obtained by comparing the market value ratio of a company's stock with the book value of the company's equity (Weston and Copeland, 2001). This ratio is considered by experts to be superior compared to the previous two ratios because this ratio focuses on the current value of the company relative to the costs needed to replace it now. Tobin's Q is formulated as follows:

$$
\mathbf{Q}=\frac{(E M V+D)}{(E B V+D)}
$$

Where :

$\mathrm{Q}$ : company value

EMV : market value of equity

EBV : book value of total asset

$\mathrm{D}$ : book value of total debt 


\section{RESEARCH METHODS}

This writing method is a descriptive analysis of several studies related to the effect of good corporate governance on company performance, which in this paper is represented by ROA, and the value of the company which in this case is represented by stock prices. This writing analysis takes the results of research from researchers conducted from 2015-2019. This paper will inform the implementation of good GCG in order to have a positive effect on Company Performance and Company Value.

\section{FINDINGS AND DISCUSSION}

Good GCG implementation as stated at the beginning of the article is if a balance is created between the company manager and the company owner (eliminating agency problems). The company manager is represented by the Board of Directors, while the owner of the company is represented by the Board of Commissioners. On the other hand there is one more unit which is an extension of the Board of Commissioners to ensure the existence of the function of supervision and internal control of the company, ensuring the quality of financial reports and the effectiveness of the audit function, namely the Audit Committee.

Good GCG implementation can be represented by the role of the board of commissioners who can monitor and oversee the running of the company and can control the functions of the board of directors. In several studies, the existence of a board of commissioners, the large number of boards of commissioners and the existence of independent commissioners has a direct and significant influence on Company Value. This means that with a board of commissioners, the company's value will also increase.

Several studies related to the relationship of GCG implementation with Company Performance (ROA) and Company Value (Share Value) from 2015 - 2019 as follows:

1. According to research by Fatimah., Mardani, Ronny Malavia., Wahono, Budi., 2019 revealed that the application of GCG has a positive and significant effect on Company Value. The implementation of GCG also has a significant positive effect on the company's financial performance.

2. Research Sarafina, Salsabila., Saifi, Muhammad., 2017 found that the existence of an independent board of commissioners and board of commissioners had a significant positive effect on financial performance represented by ROA (return on assets). This means that the presence of the board of commissioners as a form of GCG implementation has a significant positive effect on company profitability as measured by ROA.

3. Research by Tertius, Melia A., Christiawan, Yulius J., 2015 found that there was no influence between the presence of the board of commissioners and the financial performance represented by the variable ROA. This means that the achievement of ROA is not influenced by the application of GCG (board of commissioners).

4. Research by Rimardhani, Helfina., Hidayat, R Rustam., Dwiatmanto., 2016 found that the existence of an independent board of commissioners had a significant negative effect on ROA. This means that the existence of an independent board of commissioners has the effect of reducing the achievement of ROA. In other words according to this study that the implementation of GCG (represented by an 
independent board of commissioners) decreases the level of profitability (ROA) of the company.

5. Sulastri's research, Eva M., Nurdiansyah, Dian H., 2017 found that the application of GCG in companies with the CGPI index had a significant positive effect on achieving ROA. This means that the application of GCG in companies with the CGPI index has a significantly increased profitability impact.

6. Aprinita's research, Beatrick S., 2016 explained that the existence of a board of commissioners had no effect on ROA. It can be interpreted that the implementation of GCG as represented by the board of commissioners has no influence on profitability.

7. The research of Putri, Rowina K., Muid, Dul., 2017 revealed that the presence of the board of commissioners had a significant negative effect on ROA. This means that the implementation of GCG as represented by the board of commissioners has the effect of reducing the company's profitability.

8. The research of Windasari, Okta., Riharjo, Ikhsan B., 2017 revealed that there was a significant positive relationship between the implementation of GCG and Company Value. GCG in this case is represented by the board of commissioners, while the Company's Value is represented by the share price. This means that the implementation of GCG in the company has a significant positive effect on stock prices, so its application is very important.

9. Research by Syafitri, Tia., Nuzula, Nila F., Nurlaily, Ferina., 2018 shows that there is a significant negative relationship between GCG and Company Value. This means that the implementation of GCG in the company has a significant negative effect on stock prices, so its implementation is very important.

10. Research by Marini, Yushita., Marina, Nisha., 2017 revealed that there was a significant positive relationship between the implementation of GCG and Company Value. This means that the implementation of GCG raises stock prices (company value).

11. Research from Tambunan, MC Sabrina., Saifi, Muhammad., Hidayat, R Rustam., 2017 states that there is a significant positive relationship between GCG implementation and firm value. This means that the implementation of GCG in the company has a positive (up) influence on the company's value.

12. Research by Pratiwi, Ryan Anugrah., 2017 found that there was a significant negative relationship between GCG implementation and company value. GCG is represented by the board of commissioners and the value of the company is represented by the share price. This means that if GCG is implemented it will reduce the value of the company (the share price will go down).

\section{CONCLUSION AND SUGESTION}

\section{Conclusions}

1. The majority of research on the relationship between the implementation of good corporate governance (GCG) and Financial Performance in this case is represented by the parameters of return on assets (ROA) and the value of the Company represented by the value of shares is significantly positive. 
2. A good GCG implementation will increase profitability (ROA) and increase the value of the company's shares

3. Research that gets the results of the relationship between GCG and ROA as well as a significant negative Share Value occurs in financial companies. This is because the implementation of GCG, which is represented by a board of commissioners, is very strict for financial companies so that it can cause things that are inversely proportional

4. Implementation of GCG is one way to overcome agency problems that often hit companies with a one-tier board system.

5. The board of commissioners who are part of the implementation of GCG in a company must also know and understand the company's business in order to provide added value to the company

\section{Recommendation}

1. This paper only describes the relationship of two variables with GCG implementation. The next article can include other variables that are relevant to the company

2. It needs to be explained more clearly the role of the board of commissioners as the implementation of GCG in overseeing and controlling the company

\section{REFERENCE}

Ali,H (2020), 'Modul ke : 2 Concepts and Theories of Business Introduction', Universitas Mercu Buana

Onasis, RK (2016), 'Pengaruh Tata Kelola Perusahaan Terhadap Nilai Perusahaan Sektor Keuangan Yang Terdaftar di BEI', Jurnal Bina Ekonomi, Vol.20 No.1

Tertius,MA., Christiawan,YJ (2015), 'Pengaruh Good Corporate Governance terhadap Kinerja Perusahaan pada Sektor Keuangan', Business Accounting Review, Vol.3 No.1, pp: 223-232

Harsalim,JP (2017), 'Pengaruh Good Corporate GovernanceTerhadap Kinerja Keuangan Pada Peserta CGPI Yang Terdaftar di BEI Periode 2008 - 2013', Jurnal Ilmiah Mahasiswa Universitas Surabaya, Vol.6 No.2

Rimardhani,H., Hidayat,RR., Dwiatmanto (2016), 'Pengaruh Mekanisme Good Corporate Governance Terhadap Profitabilitas Perusahaan (Studi Pada Perusahaan BUMN Yang Terdaftar Di BEI Tahun 2012-2014)', Jurnal Administrasi Bisnis, Vol.31 No.1, pp: 167-175

Sarafina,S., Saifi,M (2017), 'Pengaruh Good Corporate Governance Terhadap Kinerja Keuangan dan Nilai Perusahaan (Studi Pada BUMN Yang Terdaftar di BEI Periode 2012-2015', Jurnal Administrasi Bisnis, Vol.50 No.3, pp: 108-117

Sulastri,EM., Nurdiansyah, DH (2017), 'Pengaruh Good Corporate Governance Terhadap Kinerja dan Nilai Perusahaan (Studi Pada Perusahaan Yang Terindeks oleh CGPI)', Manajerial, Vol.2 No.2, pp: 35-45

Aprinita,BS (2016), 'Pengaruh Good Corporate Governance Terhadap Kinerja Keuangan Pada Perusahaan Sektor Consumer GoodsYang Terdaftar di BEI Tahun 2012-2014, Jurnal Bisnis dan Manajemen, Vol.52 No.11, pp: 32-53 
Tambunan,MS., Saifi,M., Hidayat,RR (2017), 'Pengaruh Good Corporate Governance Terhadap Nilai Perusahaan (Studi Pada Perusahaan Sub Sektor Foob and Beverages Yang Terdaftar di BEI Tahun 2012-2015), Jurnal Administrasi Bisnis, Vol.53 No.1, pp: 49-57

Putri,RK., Muid,D (2017), 'Pengaruh Good Corporate Governance Terhadap Kinerja Perusahaan', Diponegoro Journal of Accounting, Vol.6 No.3, pp: 1-9

Marini,Y., Marina,N (2017), 'Pengaruh Good Corporate Governance Terhadap Nilai Perusahaan’, Jurnal Humaniora, Vol.1 No.1, pp: 7-20 